\title{
Histological characteristics of the musculus longissimus lumborum et thoracis muscle fibres in pigs in relation to selected RYR1, MYOG, MYOD1 and MYF6 genotypes
}

\author{
Roman Stupka, Jaroslav Č́tek, Michal Šprysl, Monika Okrouhlá, Luboš Brzobohatý, \\ Luděk Stádník, Lukáš Zita \\ Czech University of Life Sciences Prague, Faculty of Agrobiology, Food and Natural Resources, Department of \\ Animal Husbandry, Prague, Czech Republic \\ Received October 22, 2013 \\ Accepted April 24, 2014
}

\begin{abstract}
Histochemical and biochemical muscle fibre properties are the factors that influence the quantitative and qualitative characteristics of pork meat. The aim of the study was to assess the influence of genetic effects of selected genetic markers MyoD genes and RYRl on the achieved indicators of muscle fibres in the musculus longissimus lumborum et thoracis (MLLT). The study included a total number of 216 hybrid pigs with the mean slaughter weight of $123 \mathrm{~kg}$. Gene polymorphism was determined by the PCR-RFLP method. The gene polymorphism was determined in the RYR1, MYOD1, MYOG, and MYF6 genes. Muscle fibre types from MLLT were identified. Concerning the $R Y R l$ gene, the study found that homozygous-dominant animals reached a lower number of type I ( 8.35 vs. $10.52 ; P<0.05)$ and a higher number of IIA (3.66 vs. $2.10 ; P<0.05)$ and a higher number of IIB (76.61 vs. $67.91 ; P<0.05)$. The maximum number in all types of muscle fibres reached BB genotype of the $M Y O G$ gene (type I: 14.02; IIA: 18.47; IIB: 83.08; $P<0.05)$. The AA genotype of the $M Y O D 1$ gene showed the lowest $(P<0.05)$ number of muscle in all fibre types (type I: 9.20; IIA: 0.85; IIB: 69.23). The influence of individual genotypes of selected genes on the selected muscle fibre characteristics was proven. The obtained results confirm the possibility of affecting the quality of pork with genomic selection of MyoD genes family.
\end{abstract}

Pig, genome, MyoD genes, tissue, skeletal muscle, muscle microstructure

Most of the muscle mass consists of a mixture of bright and dark fibres. Dark muscles contain predominantly type I and IIA fibres (red fibres), whereas bright muscles contain primarily type IIB fibres (white fibres) (Karlsson et al. 1999). Histochemical and biochemical muscle fibre properties, such as type, size, oxidative and glycolytic capacity, fat and glycogen content are all factors that influence the quantitative and qualitative characteristics of pork meat (Bulotiene and Jukna 2008). In terms of genetic determination, muscle creation is influenced by a number of candidate genes, such MYOD1, MYF4, MYOG, MYF6, and RYRl (Blais et al. 2005). The RYRl gene was localized with the use of in situ hybridization on the 6q12 chromosome. Fujii et al. (1991) inform about a single-point $R Y R 1$ gene mutation g. $1843 \mathrm{C}>\mathrm{T}$, which is related to malignant hyperthermia in pigs. Changes in the $R Y R l$ gene influence the cell membrane of muscle cells and lead to an increased release of the $\mathrm{Ca}^{2+}$ ions from the sarcoplasmic reticulum, as a response to stress stimuli (Dvořáková et al. 2012). The MYOD1 gene was located on the $2^{\text {nd }}$ chromosome (Soumillion et al. 1997), in the 2p1.4-1.7 area. MYOD1 gene induces the differentiation of fibroblasts and their transformation into myoblasts. According to Kitzmann et al. (1998), this gene inhibits the cell cycle proliferation of myoblasts and thus sends an effective signal for their differentiation and formation into complete muscle fibres. In addition to that, this gene is also important for the myogenin activation (Wang and Jaenish 1997), which means that its activity also affects the final muscle cell differentiation. The $M Y O G$ gene

Address for correspondence:

Doc. Ing. Roman Stupka, CSc.

Czech University of Life Sciences Prague

Department of Animal Husbandry

Faculty of Agrobiology, Food and Natural Resources

16521 Prague 6, Czech Republic 
was located on the $9^{\text {th }}$ chromosome, in the 9q2.1-2.6 area (Ernst et al. 1998). Myogenin $(M Y O G)$ plays a key role in muscle differentiation and controls the start of myoblast fusion and myofibril formation (Soumillion et al. 1997). The MYF6 gene was located on the $5^{\text {th }}$ chromosome in the 5q2.5 area (Vykoukalová et al. 2003). The MYF6 gene participates in regulating the fusion of satellite cells with myofibrils and generally oversees muscle regeneration. The aim of the study was to assess the influence of genetic effects of selected genetic markers MYOD1, MYOG, MYF6 and RYRl on muscle fibre indicators in the loin, mainly because of their potential direct impact on the achieved pork quality.

\section{Material and Methods}

Animals

The study included a total number of 216 hybrid pigs, of which 144 were hybrids of the Pietrain $\times$ (Large White dam line $\times$ Landrace) $\left[\mathrm{PN} \times\left(\mathrm{LW}_{\mathrm{D}} \times \mathrm{L}\right)\right]$ genotype and 72 were hybrids of the $\left(\right.$ Pietrain $\times$ Large White $\left.{ }_{\text {sire line }}\right) \times$

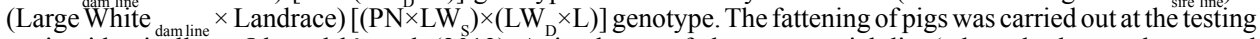
station identically to Okrouhlá et al. (2013). Animals were fed a commercial diet (wheat, barley, soybean meal and a premix of supplements of essential elements) ad libitum. Their nutritional values were adjusted continuously throughout the study according to age and body weight (BW). After the test, the animals with a mean BW of $123 \mathrm{~kg}$ were slaughtered. All pigs were slaughtered according to protocols for certified national (Czech Republic) slaughterhouses under the control of an independent veterinarian.

\section{Determination of gene polymorphism}

Gene polymorphism was determined by the PCR-RFLP method. The RYRl gene polymorphism was determined according to Fujii et al. (1991); MYOD1 according to Knoll et al. (1997); MYOG according to Soumillion et al. (1997); and MYF6 was determined by the method used by Vykoukalová et al. (2003).

Muscle fibre determination

Samples of the musculus longissimus lumborum et thoracis (MLLT) muscle, sized $5 \times 5 \times 20 \mathrm{~mm}$, were collected for the analysis, labelled and frozen with the use of liquid nitrogen. The samples were kept in a deep freezer at a temperature of $-80{ }^{\circ} \mathrm{C}$ until the time of analysis. Muscle fibre type identification in muscle samples was carried out using the Grześ optical microscope with camera (CAMEDIA-5060, OLYMPUS); the images of obtained preparations were evaluated using image analysis NIS - Elements. The following indicators were obtained: the number of fibres of type I, IIA, IIB per $0.5 \mathrm{~mm}^{2}$ area; fibres of type I, IIA, IIB proportion out of the total number of fibres per $0.5 \mathrm{~mm}^{2}(\%)$; the mean cut area of muscle fibres of type I, IIA, IIB $\left(\mu \mathrm{m}^{2}\right)$, the mean diameter of muscle fibres of type I, IIA, IIB $(\mu \mathrm{m})$ as well as the mean circumference of the muscle fibres of type I, IIA, IIB $(\mu \mathrm{m})$.

Table 1. Relative frequencies of genotypes and alleles of the RYR1, MYOG, MYOD1 and MYF6 in 216 hybrid pigs.

\begin{tabular}{|c|c|c|c|c|c|}
\hline Locus & Genotype & $\begin{array}{l}\text { Genotype } \\
\text { frequency }\end{array}$ & $\chi^{2}$-test & Allele & $\begin{array}{l}\text { Alleles } \\
\text { frequency }\end{array}$ \\
\hline RYRI & $\mathrm{NN}$ & 0.86 & $1.31^{\mathrm{NS}}$ & $\mathrm{N}$ & 0.93 \\
\hline \multirow[t]{2}{*}{$(\mathrm{n}=91)$} & $\mathrm{Nn}$ & 0.14 & & $\mathrm{n}$ & 0.07 \\
\hline & $\mathrm{nn}$ & 0.00 & & & \\
\hline$M Y O G$ & AA & 0.53 & $3.53^{\mathrm{NS}}$ & $\mathrm{A}$ & 0.75 \\
\hline \multirow[t]{2}{*}{$(\mathrm{n}=87)$} & $\mathrm{AB}$ & 0.44 & & B & 0.25 \\
\hline & $\mathrm{BB}$ & 0.03 & & & \\
\hline MYODI & AA & 0.32 & $2.35^{\mathrm{NS}}$ & $\mathrm{A}$ & 0.59 \\
\hline \multirow[t]{2}{*}{$(\mathrm{n}=90)$} & $\mathrm{AC}$ & 0.55 & & $\mathrm{C}$ & 0.41 \\
\hline & $\mathrm{CC}$ & 0.13 & & & \\
\hline MYF6 & AA & 0.03 & $64.84^{* *}$ & $\mathrm{~A}$ & 0.50 \\
\hline \multirow[t]{2}{*}{$(\mathrm{n}=90)$} & $\mathrm{AB}$ & 0.94 & & B & 0.50 \\
\hline & BB & 0.03 & & & \\
\hline
\end{tabular}

**Significant difference (the population is not in $\mathrm{H}-\mathrm{W}$ equilibrium) $P<0.01$; ${ }^{\mathrm{N} S}$ non-significant 


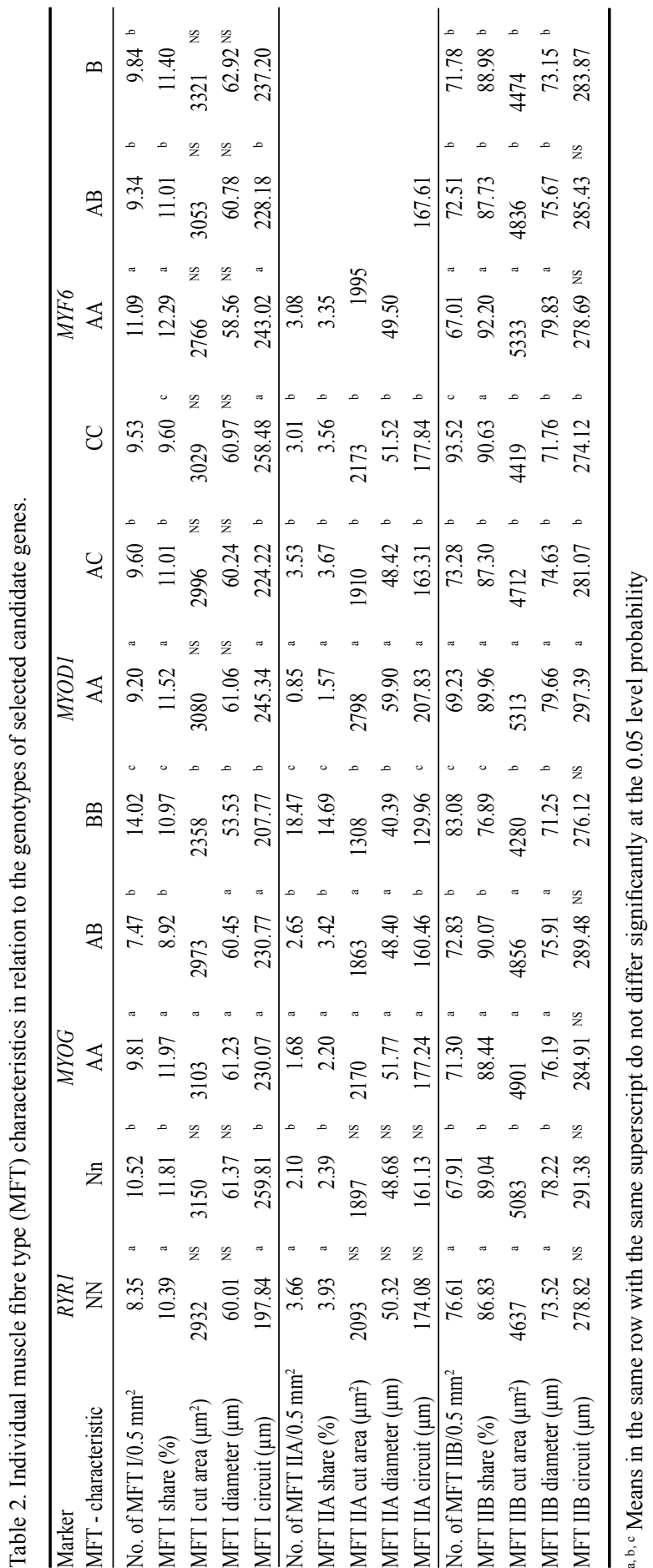

Statistical analysis

The experimental results were analysed by statistical methods, using the SAS (9.1 Institute) program and its procedures UNIVARIATE, MEANS, GLM (type IV). The differences between the observed characteristics were subjected to variance analysis. In order to evaluate the effect of genotypes of the RYRI, MYOG, MYODI and MYF6 genes and also the effects of sex, hybrid combination and carcass weight, the following model was used $Y_{i j k l m n}=\mu+R_{i}+G_{j}+S_{k}+$ $\mathrm{H}_{1}+\beta_{\mathrm{m}}+\mathrm{e}_{\mathrm{ijkkmn}}$. Where: $\mu$-population mean, $R_{\mathrm{i}}-$ fixed effect of the gene $R Y R 1$ genotypes (NN, Nn), $\mathrm{G}_{-}$- fixed effects of the genes MYOG (AA, AB, BB), MYODI (AA, AC, CC), MYF6 (AA, AB, BB) genotypes, $\mathrm{S}_{k}$ - fixed effects of sex (barrows, gilts), $\mathrm{H}_{1}-$ fixed effects of the hybrid combination $\left[\mathrm{PN} \times\left(\mathrm{LW}_{\mathrm{D}} \times \mathrm{L}\right),\left(\mathrm{PN} \times \mathrm{LW}_{\mathrm{S}}\right) \times\left(\mathrm{LW}_{\mathrm{D}} \times \mathrm{L}\right)\right]$, $\beta_{\mathrm{m}}$ - carcass weight regression, $\mathrm{e}_{\mathrm{i} \mathrm{jklmn}}$ residual error.

\section{Results}

The allele frequencies were measured in 216 hybrid pigs (Table 1). All of the polymorphic systems were in the Hardy-Weinberg equilibrium with the exception of the MYF6 gene. The study detected significant differences between the genotypes of the RYRl gene (Table 2). Differences were found in the number and proportion of the type I, IIA and IIB muscle fibres. Heterozygous $(\mathrm{Nn})$ individuals had a higher muscle fibre proportion in favour of type I (11.81\%) and IIB (89.04\%) compared to the homozygousdominant animals (10.39\%, $86.83 \%$ ). Concerning the type IIA muscle fibres, the observed tendencies were reversed. A larger proportion of these fibres were found in homozygotes (3.93\%) compared to heterozygotes $(2.39 \%)$. Muscle fibre size, expressed as a cutting area or diameter, showed the 
same trend as the number of fibres per given area. Heterozygous individuals achieved a greater area of cut and diameter type I and IIB muscle fibres compared to dominant homozygotes. Based on the above information it can be said that the RYRl heterozygotes show a higher number of type I and IIB large muscle fibres, and a lower number of type IIA smaller fibers, contrary to the values found in $R Y R 1$ dominant homozygotes. Verifying the influence of the $M Y O G$ gene on different types of muscle fibre proportion, the highest number of type I, IIA and IIB muscle fibres was found in the BB genotype. Compared to other genotypes, these fibres also had the smallest area of cut and diameter. The largest area of cut as well as the largest diameter were observed for the muscle fibres of type I, IIA and IIB of the AA genotype. Regarding the influence of the MYODl gene on the proportion and origin of muscle fibres of type I, IIA and IIB, it can be said that significantly the lowest number of muscle fibres of all the three types were determined in animals carrying the AA genotype, which is the same finding as for the $M Y O G$ gene with the exception of type I (the lowest genotype AB). The largest number of muscle fibres of type I (9.60) and IIA (3.53) were detected in individuals with the AC genotype. These muscle fibres, however, had the smallest area of cut $\left(2996 \mu \mathrm{m}^{2} ; 1910 \mu \mathrm{m}^{2}\right)$ as well as the smallest diameter values $(60.24$ $\mu \mathrm{m}, 48.42 \mu \mathrm{m})$. When assessing the impact of the MYF6 gene on the type IIA muscle fibre formation, no individual carrying the AA and BB genotype was found. Type IIA fibre was thus found only for the AB genotype. Regarding the mean number of muscle fibres of type I, significantly the highest values (11.09) were reached by individuals of the AA genotype. The highest number of type IIB muscle fibres were found in the AB genotype, with values reaching 72.51 .

\section{Discussion}

When evaluating the impact of 4 selected candidate genes on the quantitative and qualitative characteristics of muscle fibres, it can be said that homozygous-dominant animals with the RYRI gene have a significantly lower number of larger (type I) muscle fibres compared to the heterozygotes. These fibres also display a smaller area of cut and diameter. The same conclusions were reached by Grześ et al. (2010). When assessing the impact of the $M Y O G$ gene, significantly the highest number of muscle fibres per area unit were achieved by animals of the BB genotype, whereas animals of the AA genotype (with the exception of type I genotype $\mathrm{AB}$ ) showed opposite results. Contrary to our results, Jiusheng et al. (2009) reported the highest number of muscle fibres per area unit in animals having the $\mathrm{AB}$ genotype in the $M Y O G$ gene, and the lowest number in animals of the BB genotype. They further discovered (in accordance with our results), that animals carrying the $\mathrm{AB}$ genotype of the $M Y O G$ gene showed the smallest muscle fibre cut area and diameter. Regarding the influence of the MYOD1 gene, Lee et al. (2012) concluded that individual genotypes have a significant effect on different types of muscle fibre characteristics. It was demonstrated, in accordance with Klosowska et al. (2004), that the $\mathrm{CC}$ genotype in type IIB is associated with higher number of muscle fibres with a smaller area and diameter. Klosowska et al. (2004) further inform about a significant effect of the $M Y O D 1$ gene on the proportion of fast glycolytic white (IIB) fibres. Their study found the largest proportion of these fibres in the AC genotype, which, however, does not correspond with our results. It can be concluded that the effect of genotype on selected quantitative and qualitative characteristics of muscle fibres for the genes RYR1, MYOG and MYOD1 has been demonstrated.

\section{References}

Blais A, Tsikitis M, Acosta-Alvear D, Sharan R, Kluger Y, Dynlacht BD 2005: An initial blueprint for myogenic differentiation. Gene Dev 19: 553-569 
Bulotiene G, Jukna V 2008: The influence of muscle fibre area on pork quality. Vet Zootech-Lith 42: 34-37

Dvořáková V, Bartenschlager H, Stratil A, Horák P, Stupka R, Č́tek J, Šprysl M, Hrdlicová A, Geldermann H 2012: Association between polymorphism in the FTO gene and growth and carcass traits in pig crosses. Genet Sel Evol 44: 13

Ernst CW, Mendez EA, Robic A, Rothschild MF 1998: Rapid communication: Myogenin (MYOG) physically maps to porcine chromosome 9q2.1-q2.6. J Anim Sci 76: 328

Fujii J, Otsu K, Zorzato F, De Leon S, Khanna VK, Weiler JE, O’Brien PJ, MacLennan DH 1991: Identification of a mutation in porcine ryanodine receptor associated with malignant hyperthermia. Science 253: 448-451

Grześ B, Pospiech E, Koćwin-Podsiadla M, Łyczyński A, Krzecio E, Mikolajczak B, Iwańska E 2010: Relationships between the polymorphism of myosin heavy chains and selected meat quality traits of pigs with different susceptibility to stress. Arch Tierzucht 53: 65-72

Jiusheng W, Yuehuan L, Ningying X 2009: Histological characteristics of musculus longissimus dorsi and their correlation with restriction fragment length polymorphism of the myogenin gene in Jinghua $\mathrm{x}$ Pietrain F2 crossbred pigs. Meat Sci 81: 108-115

Karlsson AH, Klont RE, Fernandez X 1999: Skeletal muscle fibres as factors for pork quality. Livest Prod Sci 60: $255-269$

Kitzmann M, Carnac G, Vandromme M, Primig M, Lamb NJC 1998: The muscle regulatory factors MyoD and Myf-5 undergo distinct cell cycle-specific expression in muscle cells. J Cell Biol 142: 1447-1459

Klosowska D, Kuryl J, Elminowska-Wenda G, Kapelanski W, Walasik K, Pierzchala M, Cieslak D, Bogucka J 2004: A relationship between the PCR-RFLP polymorphism in porcine MYOG, MYOD1 and MYF5 genes and microstructural characteristics of $\mathrm{m}$. longissimus lumborum in Pietrain $\mathrm{x}$ (Polish Large White $\mathrm{x}$ Polish Landrace) crosses. Czech J Anim Sci 49: 99-107

Knoll A, Nebola M, Dvořák J, Čepica S 1997: Detection of a DdeI PCR-RFLP within intron 1 of the porcine MYOD1 (MYF3) locus. Anim Genet 28: 321

Lee EA, Kim JM, Lim KS, Ryu YC, Jeon WM, Hong KC 2012: Effects of variation in porcine MYOD1 gene on muscle fiber characteristics, lean meat production, and meat quality traits. Meat Sci 92: 36-43

Okrouhlá M, Stupka R, Čítek J, Šprysl M, Brzobohatý L 2013: Effect of dietary linseed supplementation on the performance, meat quality, and fatty acid profile of pigs. Czech J Anim Sci 58: 279-288

Soumillion A, Erkens JHF, Lenstra JA, Rettenberger G, te Pas MFW 1997: Genetic variation in the porcine myogenin gene locus. Mamm Genome 8: 564-568

Vykoukalová Z, Knoll A, Dvořák J, Rohrer GA, Čepica S 2003: Linkage and radiation hybrid mapping of the porcine MYF6 gene to chromosome 5. Anim Genet 34: 238-240

Wang Y, Jaenish R 1997: Myogenin can substitute for Myf5 in promoting myogenesis but less efficiently. Development 124: 2507-2513 